\title{
Modeling Of Non-Oil And Gas Export Forecasting Aceh Province Using Arima And Double Exponential Methods
}

\author{
Razali Abdullah ${ }^{1}$, Syarifuddin Hasyim² ${ }^{2}$ Husaini $^{3}$ \\ \{razali.abdullah@serambimekkahac.id ${ }^{1}, \underline{\text { husibram@gmail.com²}}$, syafriudin_hasyim@unsyiah.ac.id ${ }^{3}$ \} \\ ${ }^{1}$ Faculty of Teaching and Education, University of Serambi Mekkah, Jalan Teungku Imum Lueng Bata, \\ Batoh, Banda Aceh 23245 Indonesia \\ ${ }^{2}$ FacultyofLaw, Syiah KualaUniversity, BandaAceh,Indonesia \\ ${ }^{3}$ Faculty of Teacher Training and Education Syiah Kuala University, Teuku Nyak Arif Street Darussalam \\ 23111, Aceh , Indonesia,
}

\begin{abstract}
Since 2017, there have been no exports of oil and gas commodities (oil and gas) from Aceh Province, so that the commodities exported only come from non-oil and gas commodities. From 2016 to 2015, non-oil and gas exports from Aceh were dominated by urea fertilizer. However, since 2015 there has been no export of urea fertilizer and has been replaced by anhydrous ammonia. $\mathrm{K}$ arena is important to model forecasting the value of non-oil exports. The model that is compared is the ARIMA and double exponential methods. The result is the ARIMA method is better in modeling the value of non-oil exports. The results of forecasting non-oil exports in Aceh Province in 2016 showed an increase compared to 2017.
\end{abstract}

Keywords: non oil and gas exports , ARIMA, Double Exponential

\section{Introduction}

In many countries, international trade is one of the main factors to increase Gross Domestic Product (GDP) or economic growth. International trade also contributes to industrialization, the progress of transportation, communication, globalization, and the presence of multinational companies. The process of globalization that is supported by the advancement of communication and information technology has integrated a country's domestic market with international markets. Similarly, Indonesia, which is open in the process of globalization, will be easily affected by the world economic system.

World economic growth implies an increasingly large market for goods and services, especially in the era of free trade as now. This requires each country to increase the competitiveness of its commodities. The increase is related to the quality of the products produced and the resources or capital goods used. Therefore in the end international trade is not only intended as a market for domestic products, but also for the procurement of capital goods in the country that can spur industrial activities.

International trade is very much needed today, given that not all goods can be produced in their own country. Export activities mean selling goods to other countries and import means 
buying goods from other countries. Exports have an important role for the regional economy in promoting economic growth and maintaining the continuity of the national economic development process. Foreign exchange income derived from increased exports needed by the government to finance imports and the excess is a reserve of state wealth as capital to continue national development. So far, the international partnership of A ceh province has always relied on the oil and gas sector (oil and gas) as the biggest contributor to exports. The existence of oil and gas which is a natural resource that cannot be renewed certainly will not forever be able to support international trade activities. This has been proven since 2017, gas production in Aceh has been exhausted and there are no more oil and gas commodities exported abroad. So that since 2017 the international trade of the Aceh Province depends only on the non-oil and gas sector. The role of oil and gas commodities in the international trade of Aceh Province is very large. Of the total export value, more than 90 percent come from oil and gas commodities, so the absence of oil and gas commodities will greatly affect the export of Aceh Province which has dropped dramatically since the absence of oil and gas commodity exports.

Unlike oil and gas, the non-oil and gas sector comes from renewable natural resources, so that its existence will continue as long as it continues to be renewed. Therefore, with no more oil and gas production in Aceh Province, exports from non-oil and gas commodities must continue to be increased.

Formulation of the problem

Based on the background above, the formulation of the problem you want to raise in this study include the following:

1. What is the description of the export of Aceh Province from 2016 to 2017 ?

2. What is the best method for forecasting the export of Aceh Province?

3. What is the estimated export of Aceh Province for 2016 and 2017?

Research purposes

The objectives of this study are as follows:

1. Knowing the export picture of Aceh Province from 2016 to 2017.

2. Knowing the best method for forecasting the export of Aceh Province.

3. Knowing the estimated export of Aceh Province for 2016.

\section{Reference Review}

Economic problems are when human needs become unlimited, while the fulfillment of needs is limited. In addition, humans cannot fulfill their own needs, so to meet the needs they cannot produce, humans trade with other people. The beginning of the existence of trade is because often someone wants something he does not have and it can be obtained from someone else who happens to also want something from someone else he does not own [1]

This trade is expected to benefit both parties. This situation makes people take advantage of the comparative advantage they have, whether it is in the form of a certain wealth of resources or scientific ability.

A country can trade with other countries. This is what is called international trade. The role of international trade in the country's economy can be measured in relation to gross national product ( GNP). Openness ( openness ) of a country's economy is measured through the role of imports and exports in GNP. Therefore, the more open the economy of a country, the more prosperous its welfare towards economic activities that take place elsewhere [2] 


\section{Result and Discussion}

\subsection{Data source}

The main data which is the subject of this research are the export value of Aceh Province every month from 2016 to 2017 collected by the Aceh Province Central Statistics Agency (BPS).

\subsection{Analysis Method}

Holt (1957) developed an exponential smoothing method that is two Holt parameters that are able to develop local trends in time series. This means that Holt is able to explain trend trends not only between two points, but can explain trends in time series. The three equations used by the Holt method are:

1. Exponential smoothing or current level estimation

2. Estimated trend

$$
S_{t}={ }_{\propto} X_{t}+(1-\propto)\left(S_{t-1}+b_{t-q}\right)
$$

$$
b_{t}={ }_{\gamma}\left(S_{t}-S_{t-1}\right)+(1-\gamma) b_{t-1}
$$

3. $\quad P$ periods ahead forecast

Where:

$$
F_{t+m}=S_{t}+m b_{t}
$$

$\mathrm{T}_{\mathrm{t}}=$ New smoothing value

$\alpha \quad=$ Data smoothing constant $(0 \leq \alpha \leq 1)$

$\mathrm{X}_{\mathrm{t}}=$ A new observation for the actual value in the series in period $t$

$\gamma \quad=$ Constant smoothing for trend estimation $(0 \leq \gamma \leq 1)$

$\mathrm{b}_{\mathrm{t}} \quad=$ Estimated trend

$\mathrm{m} \quad=$ The predicted period ahead

The next method used is ARIMA (Auto Regressive Integrated Moving Average), where this method is only based on the behavior of the observed variable data. This method uses information in the series itself to produce predictions. This is different from previous forecasting techniques with structural models of both causal and simultaneous models where the model equation shows the relationship between economic variables. The main reason for using this method is because the movements of the economic variables studied such as exchange rate movements, stock prices, and inflation are often difficult to explain by economic theories. After being tested, it turns out that a simpler forecasting like the ARIMA model gives more powerful results than forecasting with the causality model. The ARIMA model was developed more in depth by two GEP Box statisticians and GM Jenkins. For this reason, ARIMA modeling and forecasting often refers to the Box-Jenkins methodology .

In the Auto Regressive (AR), Moving Average (MA), and ARMA (Auto Regressive-Moving Average) models require that the time series data observed has stationary properties. Time series data is said to be stationary if it meets three criteria, namely if time series data has a constant average, variant, and covariance. But in reality time series data is often not stationary but stationary in the differenceprocess. The difference process is a process of looking for differences between one period and another period in sequence. The resulting data is called the first level data difference.

If the time series data used is not stationary at the level, then the data is likely to be stationary through the difference process or in other words if the data is not stationary at the level, then it needs to be stationary at the level of difference. This model 
with stationary data through differencing process is called ARIMA model. Thus, if the data is stationary through the differencing process and timesapplying the $\operatorname{ARMA}(p, q)$, then the model is $\operatorname{ARIMA}(p, d, q)$ where $p$ is the level, $d$ the process level makes the data stationary, and $q$ is the MA level.

\subsection{Overview of the Export of Aceh Province from 2016 to 2017}

Based on the table below it can be seen that the value of non-oil exports in Aceh Province in general tends to decline since 2016 to 2017. The decline in non-oil and gas exports is due to the absence of fertilizer exports since 2015. This is coupled with the prohibition of the export of raw oil since 2016, so that in the period of 2015 to 2017 the value of non-oil and gas exports continued to decline.

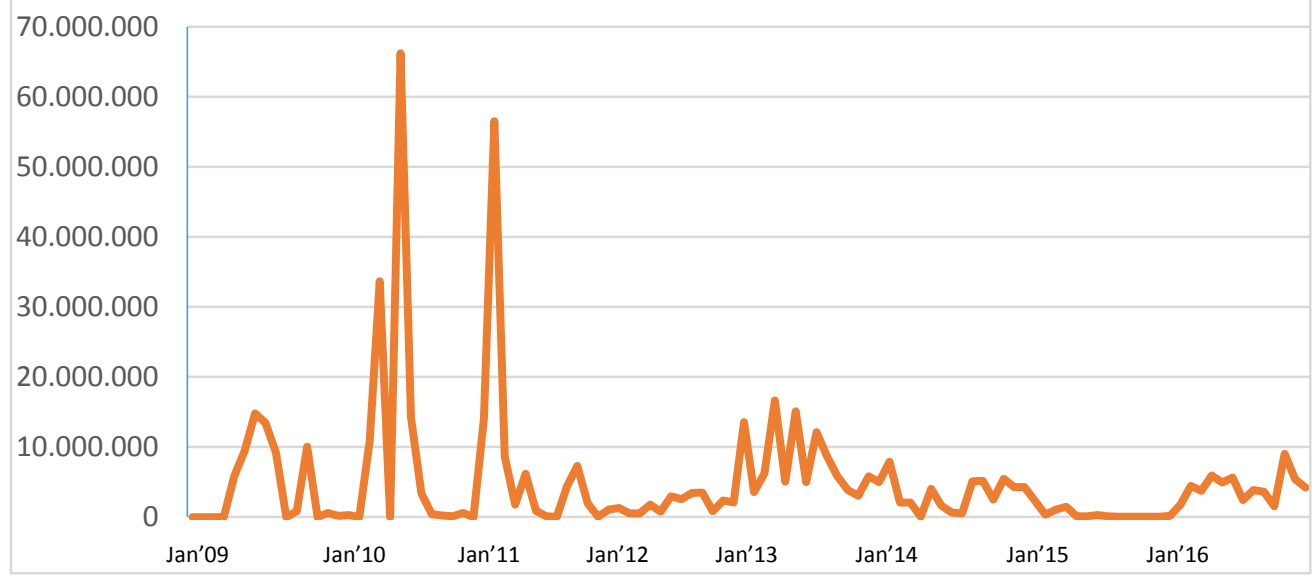

Figure 1. Value of Non-Oil and Gas Exports for the Province of Aceh in 2016-2017 Source: BPS Aceh Province

In the period of 2010 and , the value of non-oil and gas exports from the province of Aceh was very large compared to other years. The biggest commodity exported during this period was ureafertilizer from PT Pupuk Iskandar Muda (PIM). Share of fertilizer commodities in 2010 amounted to 93.50 percent of total exports, while in it was 91.17 percent of total exports. In 2010 and 2013 the export value of urea fertilizer was not too large compared to previous years. As a result, the total value of non-oil and gas exports in the province of Aceh experienced a drastic decline. In the second year, the role of urea fertilizer was replaced by an inorganic chemical commodity in the form of anhydrous ammonia. The two commodities are still from PT Pupuk Iskandar Muda.This shows the changes in the commodities exported by PT PIM, where in 2010 and in the form of urea fertilizer, in 2013 and 2013 it became anhydrous ammonia .

In 2014, the value of urea fertilizer commodities increased again compared to the previous two years. This makes the export value of Aceh in 2014 increase again. In addition, there are still commodities of inorganic chemicals in the form of anhydrous ammonia. Share of these two commodities to the total SP spor in 2014 was 82.72 percent.

As mentioned earlier that in 2015 there were no more export of urea fertilizer commodities. This makes the value of Aceh exports fall again, this is also coupled with the prohibition of raw mineral commodity exports in 2016. So that in 2015 and 2016 the export value of Aceh Province experienced a decline. 
In 2017, the value of non-oil and gas exports in Aceh Province again experienced an increase compared to the previous two years. The composition of non-oil and gas exports, among others, comes from the following commodities:

Table 1. Non-Oil and Gas Commodities Exported in 2017

\begin{tabular}{|c|c|c|}
\hline $\begin{array}{c}\text { HS Code } \\
(1)\end{array}$ & $\begin{array}{c}\text { Commodity } \\
\text { (2) }\end{array}$ & $\begin{array}{c}\text { Value (US D ) } \\
\text { (3) }\end{array}$ \\
\hline 03 & Fish and Shrimp & 814,985 \\
\hline 04 & Milk, Butter, Eggs & 13,321 \\
\hline 09 & Coffee, Tea, Spices & 161,850 \\
\hline 25 & Salt, Sulfur, Lime & 5,192 \\
\hline 27 & Mineral fuels & $21,934,647$ \\
\hline 28 & Inorganic chemicals & $30,649,079$ \\
\hline 46 & Straw / woven material & 983 \\
\hline 72 & Iron and Steel & 4,027 \\
\hline 73 & Objects from Iron and Steel & 27,350 \\
\hline 84 & Mechanical / Aircraft Machines & 19,782 \\
\hline 87 & Vehicles and parts & 201,055 \\
\hline 89 & Ship & 727,857 \\
\hline \multicolumn{2}{|r|}{ TOTAL } & $54,560,127$ \\
\hline
\end{tabular}

From the table above it can be seen that in 2017, the largest non-oil and gas commodities exported from Aceh Province were inorganic chemicals in the form of anhydrous ammonia of 30.65 USD and mineral fuels in the form of other coal, whether or not pulverized but not agglomerated at 2193 USD. Share of the two commodities amounted to 96.38 percent.

Based on the commodities exported in 2017, it can be seen that Aceh's exports depend heavily on anhydrous ammonia and coal commodities . Commodity anhydrous ammonia is a commodity that can be renewed so that continuity can be expected for a long period of time. But it is different from coal commodities which are commodities that cannot be renewed. Its existence in nature is very limited and in a certain time will soon run out. Therefore, it is necessary to have alternative commodities to replace coal commodities if one day has run out. Furthermore, it is necessary to estimate the development of Aceh's nonoil and gas export value based on time series data from 2016 to 2017.

The process of finding the best forecasting method uses the following steps:

Divide the observation data into two, namely in-sample and out-sample. In-sample data is data that is used to obtain a forecasting model, while the data out-sample is used to select the best method to be used. The in-sample data used is non-oil and gas export data for the Province of Aceh from January 2016 to December 2016, while the out-sample data used is non-oil and gas export data for the Province of Aceh from January 2017 to December 2017

1. Modeling data using in-sample data

2. Comparison of the best model selection criteria in out-sample data

3. Selection of the best model

4. Forecasting non-oil and gas export data for Aceh Province ARIMA

The initial stage of ARIMA modeling is data stationarity. Based on the time series plot, data on non-oil exports tend to be stationary with several outliers. The stationary data on nonoil and gas exports on average can be seen through ACF and PACF plots. In the plot, the cut- 
off pattern for the 9 plots is shown. This means that only a significant lag of 9 ACF and PACF values, while in the next lag there is no significant. This shows that the data on non-oil exports has been stationary on average so there is no need for differencing.

Identification of the ARIMA model is determined from the ACF and PACF plot patterns on stationary non-oil and gas export data. From the ACF plot pattern that is formed only 9 significant lags, so also the PACF plot pattern is only a significant 9 lag. Based on this, the alleged ARIMA model that might be formed is ARIMA $(9,0,0)$ and ARIMA $(0,0,9)$. Furthermore, to determine the best model for in-sample data, the criteria for AIC and SBC are used. The results obtained that ARIMA $(9,0,0)$ is better than ARIMA $(0,0,9)$, so it can be concluded that the right modeling to predict the value of non-oil exports in Aceh Province is using ARIMA $(9.0,0)$.

Double exponential t ial

Identification of the initial model smoot $h$ ing exponential conducted with respect to the nonoil export data plot province. Based on the data plots held, it is seen that the value of non-oil exports in Aceh Province has increased and decreased. Therefore, in the exponential smoothing method chosen method of double-exponential. From the double exponential method, a double exponential equation model is obtained with values $\alpha=$ 0.949943 and $\gamma=0.010000$.

The double exponential model that is suitable for forecasting non-oil exports has the following equation:

Pemilihan Best Model

Furthermore, the calculation of the magnitude of deviations from the ARIMA $(9.0,0)$ and double exponential models with several measures of accuracy. The table below shows the value of Mean Square Error (MSE), Mean Absolute Percentage Error (MAPE), and Mean Percentage Error (MPE) for forecasting non-oil exports of Aceh Province.

Table 2. Standard Accuracy of ARIMA Models (9,0,0)and Double Exponential

\begin{tabular}{lll}
\hline Criteria & ARIMA $(9,0,0)$ & Double Exponential \\
\hline$M S E$ & $4,52445 \mathrm{E}+12$ & $1,4625 \mathrm{E}+13$ \\
$M A P E$ & 37,98629959 & 68,33256837 \\
$M P E$ & 7,591384151 & 68,33256837 \\
\hline
\end{tabular}

The choice of the best model can be seen from the comparison table of the level of accuracy of the model above. The $M S E$ value states that the average squared error error, ARIMA model $(9.0,0)$ is $4,524,446,448,789$ USD and the double exponential model is $14,624,986,286,272$ USD. MAPE indicates the absolute error rate of forecasting compared to the actual data, for the ARIMA model (9.0.0) is 37.09 percent and double exponential is 68.33 percent. The last is the $M P E$ value which shows the percentage error of the forecasting value. The ARIMA model $(9.0,0)$ has an MPE value of 7.59 percent and for double exponential is 68.33 percent.

Judging from the value of MSE, MAPE, and MPE the ARIMA model $(9.0,0)$ is smaller than the double exponential model, so it can be concluded that the use of the ARIMA model $(9.0,0)$ is the best model in predicting the value of the Province's non-oil and gas exports Aceh. Forecasting the Value of Non-Oil and Gas Exports in the Province of Aceh

After getting the best model, the final step is to do forecasting or prediction. Forecasting will use the ARIMA (9.0.0) model to forecast the data of non-oil exports in Aceh Province for 12 months in 2016. The forecasting results are as follows: 
Table 2. Forecasting the Value of Non-Oil and Gas Exports in the Province of Aceh in 2016

\begin{tabular}{ll} 
Month & Export Value \\
\hline 1 & $3,887,371$ \\
2 & $3,761,640$ \\
3 & $3,712,727$ \\
4 & $3,693,700$ \\
5 & $3,686,297$ \\
6 & $3,683,418$ \\
7 & $3,682,297$ \\
8 & $3,681,862$ \\
9 & $3,681,692$ \\
10 & $3,681,626$ \\
11 & $3,681,600$ \\
12 & $3,681,590$ \\
\hline
\end{tabular}

From the table above shows that the value of non-oil exports in Aceh Province is relatively stable throughout 2016. So from the above data it can be seen that the total value of non-oil and gas exports in Aceh Province in 2016 amounted to 44,515,819 USD.

\begin{tabular}{ll}
\hline Year & Value of Non-Oil and Gas Exports \\
\hline 2009 & $63,559,612$ \\
2010 & $129,735,630$ \\
& $88,962,520$ \\
2011 & $24,944,096$ \\
2012 & $77,258,045$ \\
2013 & $60,154,753$ \\
2014 & $33,168,833$ \\
2015 & $4,053,327$ \\
2016 & $54,560,127$ \\
2017 & $44,515,819 *$ \\
\hline & *) forecast numbers Conclusion
\end{tabular}

The best model for forecasting the value of non-oil exports of the Aceh Province ARIMA model $(9.0,0)$ is compared with the double exponential model . Forecasting the value of nonoil exports in Aceh Province in 2016 has increased compared to 2017 amounting to 18.42 percent. With the absence of oil and gas commodity exports since 2017, it is hoped that the role of non-oil and gas commodities will increase to continue to support the international trade of Aceh Province.Aceh Province, which has extensive natural resources in the form of agricultural land and plantations, has great potential if optimally empowered. Besides that the potential of the sea is also not less important, where the results of fishing in the province of Aceh are quite abundant and have very good quality for export to foreign countries.

The role of the government is expected to encourage production from the fisheries, agriculture, plantations and other sectors to be more productive by using the best methods that are effective and efficient to get optimal results. 


\section{References}

[1] M. Todaro, Third World Economic Development (eighth edition). Erlangga, 2003.

[2] N. Gemmel, Development Economics (translation). Jakarta: Library LPES, 1992.

[3] Central Bureau of Statistics (2017). Foreign Trade Statistics of the Province of Aceh

[4] De Gooijer, J. G., \& Hyndman, R. J. (2006). 25 years of time series forecasting. International journal of forecasting , 22 (3), 443-473.

[5] Gubaidullina, Tatiana \& Yakupov, Alexander . ( 2017 ). Export potential of Russian regions in the context of WTO Access . International Conference on Applied Economics

[6] Jawaid, Syed Tehseen, Qadri , Faisal Sultan , \& Ali , Nasir. (2013). Monetary Economic FiscalTrade Policy in Pakistan: Time Series Empirical Investigation. International Journal of Economics and Financial Issues, Vol. 1, No. 3, 2013, pp. 133-138

[7] Kilavuz, Emine \& Topcu, Betül Altay . (2014). Export and Economic Growth in the Case of the Manufacturing Industry: Data Panel Analysis of Developing Countries . International Journal of Economics and Financial Issues, Vol. 2, No. 2, 2014, pp.201-215

[8] Kuznetsova, Natalia Victorovna, Kocheva, Ekaterina Victorovna, \& Matev, Nikolay Anatolievich . (2016). The Analysis of Foreign Trade Activities of Russia and the Asia-pacific Region. International Journal of Economics and Financial Issues, 2016, 6 (2), 736-744

[9] Proietti, T., \& Lütkepohl, H. (2015). Does the Box Cox help in forecasting macroeconomic time series? . International Journal of Forecasting, 29 (1), 88-99.

[10] Tastan, Serkan \& Ozekicioglu, Halil .(2 014 ). Development of European Union and China Bilateral Trade After The 2010 Financial Crisis: A Cluster Analysis . International Journal of Economics and Finance Issues, Vol. 4, No. 2, 2016, pp.336-343

[11] The 2010 Financial Crisis: A Cluster Analysis . 